\title{
Isolation and Identification of Ipomoea cairica (L.) Sweet Gene IcSRO1 Encoding a SIMILAR TO RCD-ONE Protein, Which Improves Salt and Drought Tolerance in Transgenic Arabidopsis
}

\author{
Benqi Yuan ${ }^{\dagger}$, Minghao Chen ${ }^{\dagger}$ and Shaoshan $\mathrm{Li}^{*}$ (D) \\ Key Laboratory of Ecology and Environmental Science in Guangdong Higher Education, School of Life Sciences, \\ South China Normal University, Guangzhou 510631, China; yuanbenqi@m.scnu.edu.cn (B.Y.); \\ 2017022212@m.scnu.edu.cn (M.C.) \\ * Correspondence: lishsh@scnu.edu.cn; Tel.: +86-20-85211555 \\ + These authors contributed equally to this work.
}

Received: 12 November 2019; Accepted: 28 January 2020; Published: 4 February 2020

check for updates

\begin{abstract}
Ipomoea cairica is a tropical plant and a wild relative of the food plant sweet potato (Ipomoea batatas), listed as one of the most invasive alien species in China. Recently, it has been reported that I. cairica had successfully invaded mangrove wetlands, indicating its high salt tolerance. Based on previous genetic studies, I. cairica offers a good model for characterizing stress-resistant genes. It has recently been identified that the SRO proteins (SIMILAR TO RCD-ONE) play important roles in a variety of stress and developmental responses. Radical-Induced Cell Death1 (RCD1) was the first identified plant SRO protein from Arabidopsis thaliana. As a typical SRO protein, IcSRO1 had a highly conservative WWE domain, a conserved PARP fold and protein C in the RST function area. The expression of IcSRO1 was induced by salt, drought, and the plant hormone ABA. The transgenic Arabidopsis overexpressing ICSRO1 showed higher tolerance against salt and drought stress along with lower accumulation of hydrogen peroxide $\left(\mathrm{H}_{2} \mathrm{O}_{2}\right)$ and superoxide $\left(\mathrm{O}_{2}{ }^{-}\right)$than the wild type. The IcSRO1 protein was localized in the nucleus after cultivation in the buffer. Our results indicated it could interact with Arabidopsis SALT OVERLY SENSITIVE 1 (AtSOS1), suggesting IcSRO1 may have similar functions. The pleiotropic effect of IcSRO1 on physiological processes contributes to the improvement of plant tolerance against diverse abiotic stresses, and may be associated with the adaptation of I. cairica to those environments with extreme saline and drought conditions. It therefore provides valuable gene resources for crop breeding enhancement.
\end{abstract}

Keywords: Ipomoea cairica; SIMILAR TO RCD-ONE protein; gene expression; transgenic Arabidopsis; salttolerance; drought; invasive plant

\section{Introduction}

Ipomoea cairica (L.), Sweet (Convolvulaceae), is an extremely fast-growing perennial creeping liana, believed to be native from tropical Africa or South America [1-4]. In China, I. cairica started its invasion of Hong Kong in 1912, and now it has expanded widely to most of the provinces in South China [5]. This vine has invaded natural landscapes, abandoned farmland, roadsides, residential areas, and even artificial forests and has caused severe damage to ecosystems and local economies [6]. It has been listed as one of the worst invasive alien species in China [7]. It exhibits high nutrient uptake and utilization efficiency, greater resistance to many diseases and strong adaptive abilities to diverse habitats [8]. Recently, it was shown that I. cairica is resistant to salt. However, it has cross-incompatibility with closely related species in the genus Ipomoea [9]. As an important food, industrial, and energy resource 
crop, there is a dramatically increased demand for Ipomoea batatas (L.) Lam (sweet potato), but its yield is often restricted by various biotic and abiotic stresses. Based on previous genetic studies, I. cairica offers a good genetic model species for characterizing stress-resistant genes. Application of these genes in transgenic breeding is expected to improve the resistance of crops, which is also the potential value of I. cairica. [10].

Abiotic stresses are significant limiting factors that affect global crop production, including salinity and drought. At present, salinity has become a major problem suffered by $50 \%$ of the irrigated lands and over $30 \%$ of cultivated lands all around the world [11]. The increased salinization of arable land will bring about a loss of 30\% agriculture lands within two decades [12]. In China, over $1.0 \times 10^{8}$ $\mathrm{hm}^{2}$ of cultivated lands suffers from saline soils, occupying approximately $7 \%$ of the total [13]. Arid and semi-arid land also accounts for one-third of the Earth's land, and the rest has a high potential to face unexpected climatic droughts from time to time [14]. Salt and drought stress leads to severe production reduction in agriculture, and it may be feasible to meet the challenge of salinity and drought by improving the resist ability of crops using plant genetic engineering [15-19].

The function of SRO proteins, also named as SIMILAR TO RCD-ONE, participating in a variety of stress and developmental responses, has been reported recently. They are hallmarked by the domain with a conserved poly (ADP-ribose) polymerase (PARP) fold and a C-terminal RST (RCD-SRO-TAF4) domain [20]. Moreover, it is known that some SRO proteins hold a WWE domain in their N-terminal sequences $[20,21]$. Many SROs have been further investigated in various plants, including Arabidopsis [22], rice [23], wheat [24], maize [25], tomato [26], cotton [27], Brassica napus [28] and apple [29]. The first SRO protein identified from Arabidopsis thaliana is RCD1, named after its function in cell death induced by radicals. It is a stress-associated hub, reported to interact with over 30 proteins, 21 of which are recognized as transcription factors from different families [30,31]. The mutation of $A t R C D 1$ results in significantly increased sensitivity to extracellular reactive oxygen species (ROS) and suppressed resistance to methyl viologen, Ultraviolet-B irradiation, salt sensitivity, heavy metals toxicity and altered responses to hormones, as well as defects in developmental processes, such as defects in root architecture, alterations to leaf and rosette morphology, and early flowering [32-37]. The interaction between RCD1 and salt overly sensitive1 (SOS1) was detected in Arabidopsis under salinity and oxide. There is a possibility that $\mathrm{RCD} 1$ regulates the activity of $\mathrm{Na}+\mathrm{H}+$ antiporter of AtSOS1 and influence the salt tolerance [38].

In this present study, we describe the cloning and characterization of a homoeologous $R C D 1$ locus (ICSRO1) from Ipomoea cairica. Quantitative real-time PCR was used to assess the expression features of IcSRO1 under different stress treatments. Then the gene was transformed into Arabidopsis thaliana for further functional identification.

\section{Results}

\subsection{Isolation and Bioinformatics Analysis of IcSRO1 Gene}

Isolation of IcSRO1 and sequence analysis IcSRO1 was from cloned I. cairica and the open reading frame (ORF) comprising $1806 \mathrm{bp}$ was obtained by PCR, encoding a protein of 601 amino acid residues. The protein has an isoelectric point (PI) of 5.56, and its predicted molecular weight (MW) is $67.72 \mathrm{kDa}$. We further analyzed the conserved sequence of this protein and confirmed that the IcSRO1 contained a conserved WWE domain at the N-terminal of the proteins, a conserved PARP fold and a protein C-terminal RST functional domain (Figure 1). The sequence analysis revealed that it encoded a protein homologous to a series of the SIMILAR TO RCD-ONE1 (SRO) family. 
WWE

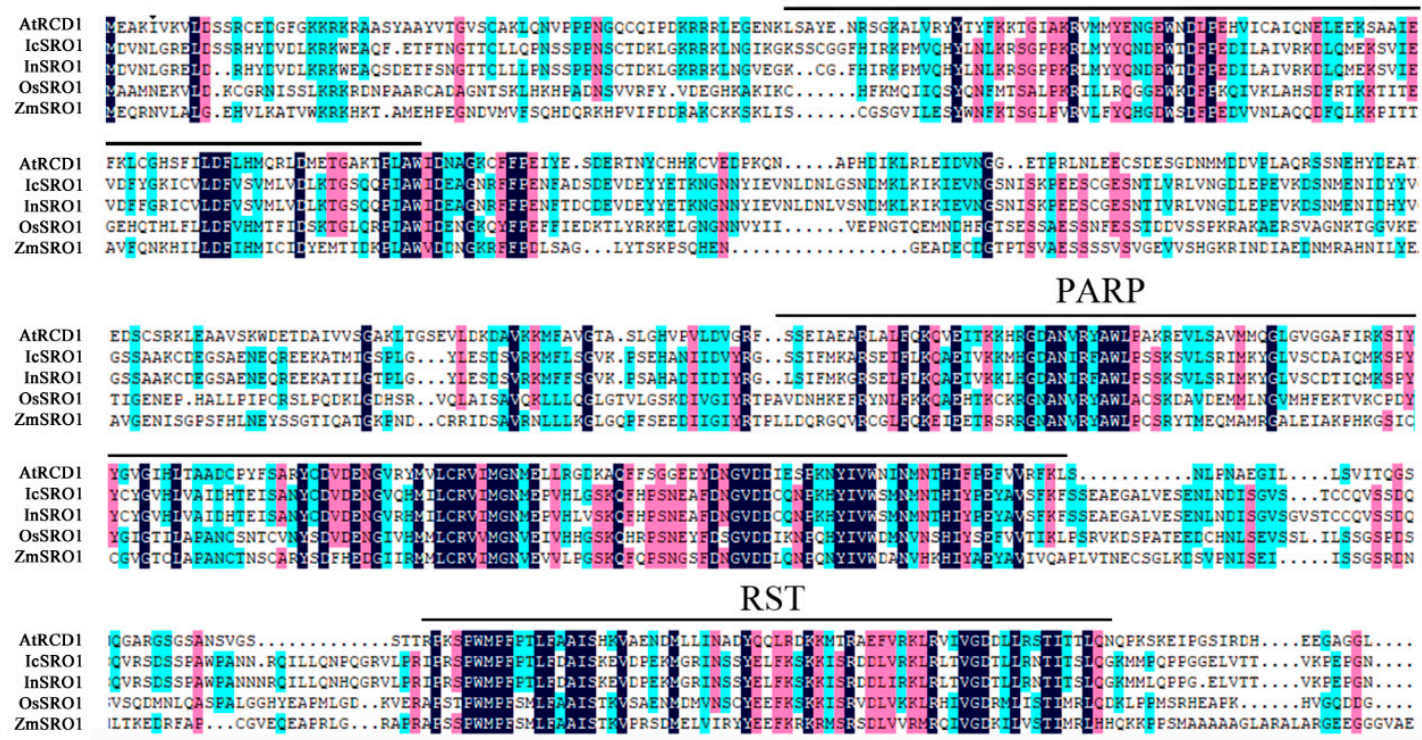

Figure 1. Sequence alignment of IcSRO1 with RCD1 from Arabidopsis thaliana and its homologies in Ipomoea batatas, Oryza sativa and Zeamays indicates that the amino acid sequence of IcSRO1 is similar to other species. N-terminal WWE domain, the core of the poly (ADP-ribose) polymerase (PARP), C-terminal RCD1-SRO-TAF4 domain (RST domain) are marked. Amino acid sequences of other genes were derived from NCBI (http://www.ncbi.nlm.nih.gov/).

The amino acid sequence of IcSRO1 indicates that it is similar to other plant SIMILAR TO RCD-ONE1 proteins (Figure 1) such as Ipomoea nil (XP_019156087.1, 93.40\%), Cuscutaaustralis (RAL45313.1 60.73\%), Capsicum annuum (XP_016550729.1 49.17\%), Nicotiana tabacum (XP_016511418.1, $50.66 \%)$, Solanum lycopersicum (XP_004244408.1, 48.93\%), Olea europaea var. sylvestris (XP_022878575.1 45.08\%), Glycine max (XP_003516978.1, 42.12\%) and Arabidopsis thaliana (NP_564391.1, 37.40\%). IcSRO1 showed high homology with morning glory (Pharbitis nil (L.) Choisy.), tobacco (Nicotiana tabacum L.), tomato (Solanum lycopersicum), and Arabidopsis. These statistics indicated that IcSRO1 has typical features of SRO-like proteins and a close relationship with some homologues in dicots. Phylogenetic analysis revealed that IcSRO1 was relative to the predicted protein products of Ipomoea nil (Figure 2). IcSRO1 and InSRO1 were modeled onto the RCD1 PARP-like structure (PDB 5NGO) using SWISS-MODEL [39]. The three-dimensional (3D) structure shows that IcSRO1, AtRCD1, and InSRO1 have some similarity in their structures (Figure 3). 


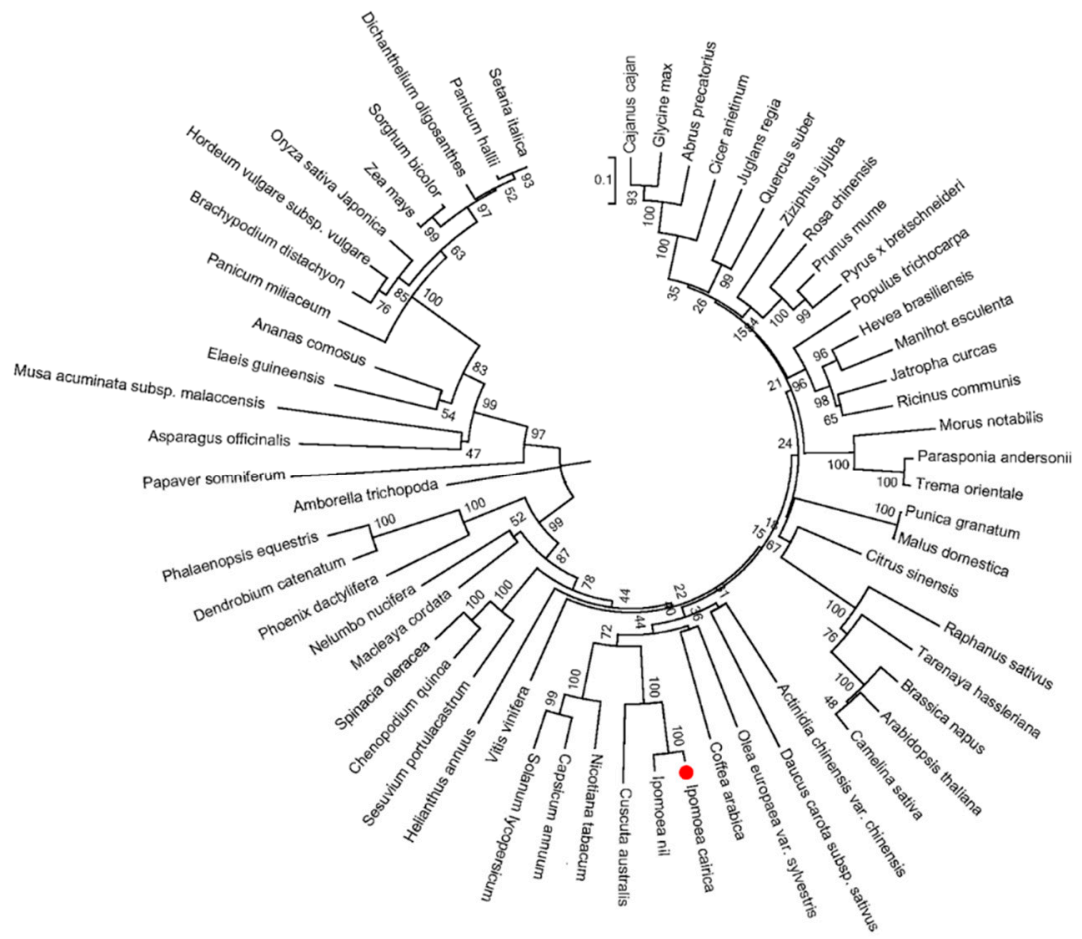

Figure 2. Phylogenetic tree of IcSRO1 and other SRO proteins revealed that IcSRO1 had a close relationship with the predicted protein products of Ipomoea nil. The tree was constructed by MEGA 6.0 software, based on alignment of complete protein sequences. The red dot indicates IcSRO1 protein.

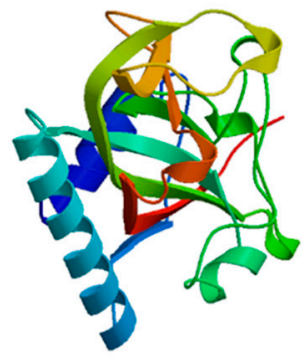

AtRCD1

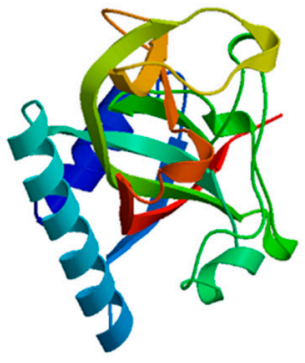

IcSRO1

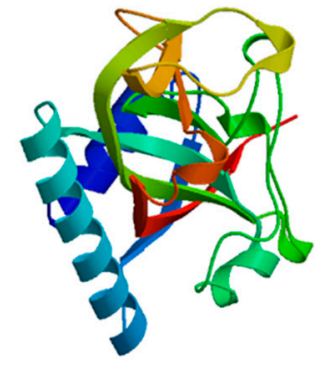

InSRO1

Figure 3. The 3D structure models show AtRCD1, IcSRO1 and InSRO1 share a similar structure. The model was constructed by SWISS-MODEL.

\subsection{Subcellular Localization of the IcSRO1 Protein}

IcSRO1-YFP fusion protein was investigated to examine the exact subcellular localization of the IcSRO1 protein. C-terminal yellow fluorescent protein (YFP) of IcSRO1-YFP was used as a marker. The protein with a single YFP was used as a control. These constructs were transformed into Arabidopsis mesophyll protoplasts. The fluorescence was detected by confocal laser-scanning microscope. The results showed that fluorescence was mainly distributed in the nucleus of the cells expressing ICSRO1-YFP fusion gene; however, the fluorescence in the cells expressing the YFP was distributed throughout the entire protoplast cell, indicating that the IcSRO1 protein was localized in the nucleus (Figure 4). 


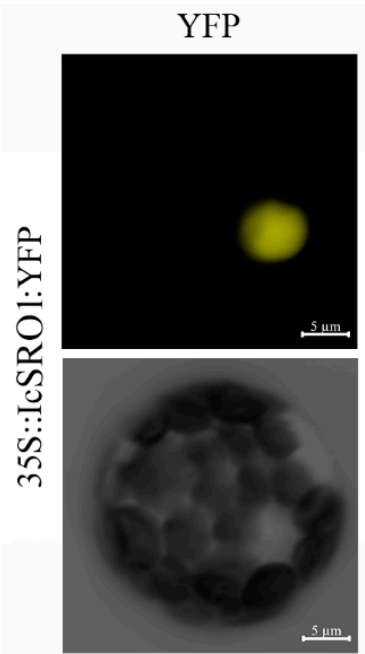

Brightfield
Chloroplast

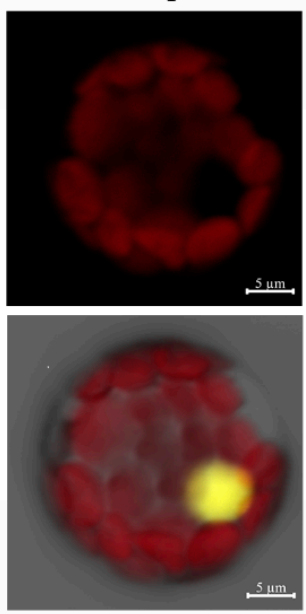

Merge

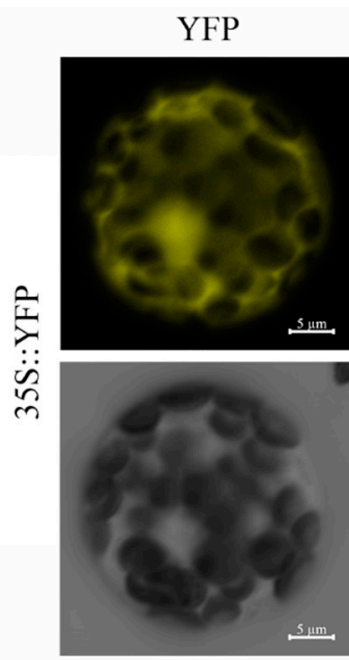

Brightfield
Chloroplast

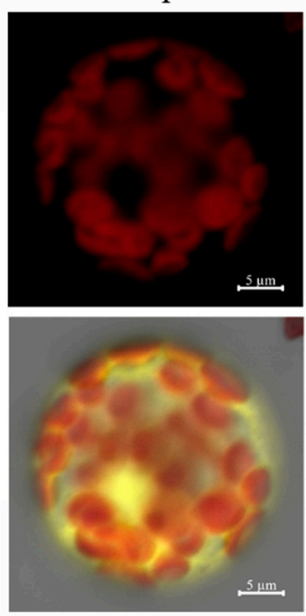

Merge

(a)

(b)

Figure 4. Subcellular localization of IcSRO1 protein. IcSRO1-YFP fusion protein was localized in nucleus of Arabidopsis mesophyll protoplast (a), while YFP was distributed throughout the entire protoplast cell (b). The yellow indicates yellow fluorescent, and the red represents chloroplast autofluorescence. Scale bars $=5 \mu \mathrm{m}$.

\subsection{Expression Pattern of IcSRO1 Gene under Different Abiotic Stresses}

To investigate the response of IcSRO1 to abiotic stresses, qRT-PCR was used to analyze the relative expression levels. The abundance of ICSRO1 transcripts changed very little in the first hour after sodium chloride $(\mathrm{NaCl})$ treatment, while subsequently appeared a dramatical increasing by approximately 3.6 folds after $6 \mathrm{~h}$, then followed by a decrease. The drought stress was stimulated by $20 \%$ polyethylene glycol (PEG). After drought, the IcSRO1 expression level increased gradually to peak at $12 \mathrm{~h}$. Similarly, IcSRO1 expression was considerably elevated by exogenous $10 \mu \mathrm{M}$ abscisic acid (ABA)(Figure 5), which can inhibit seedling and growth. In contrast, the expression of IcSRO1 under control condition showed no difference during the entire treatment. These results manifest that IcSRO1 responses to various abiotic stresses in the short term.

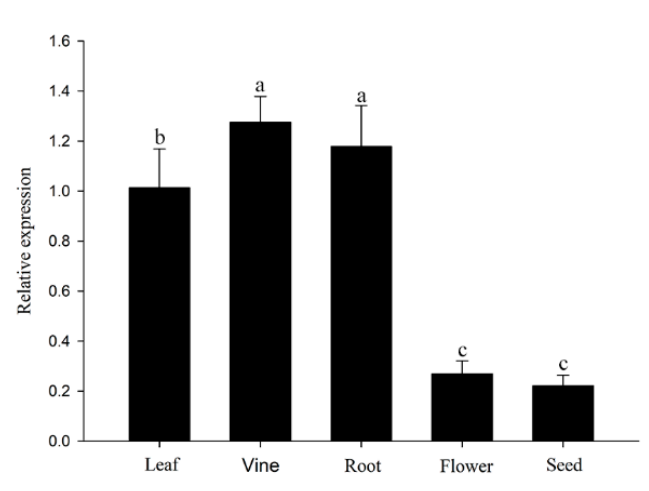

(a)

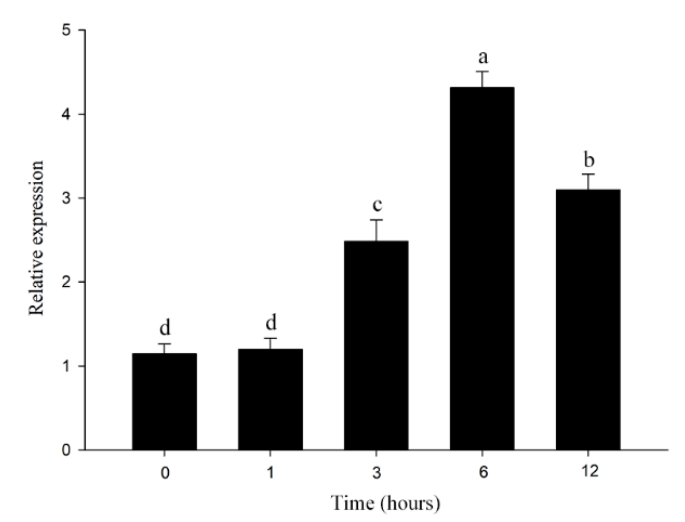

(b)

Figure 5. Cont. 


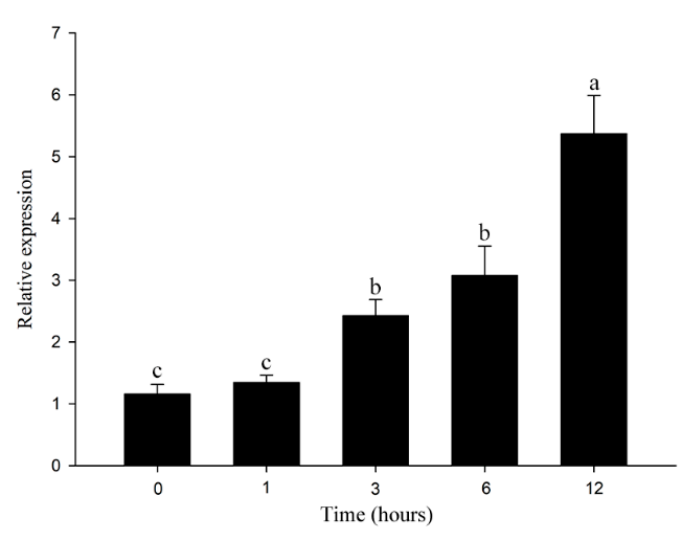

(c)

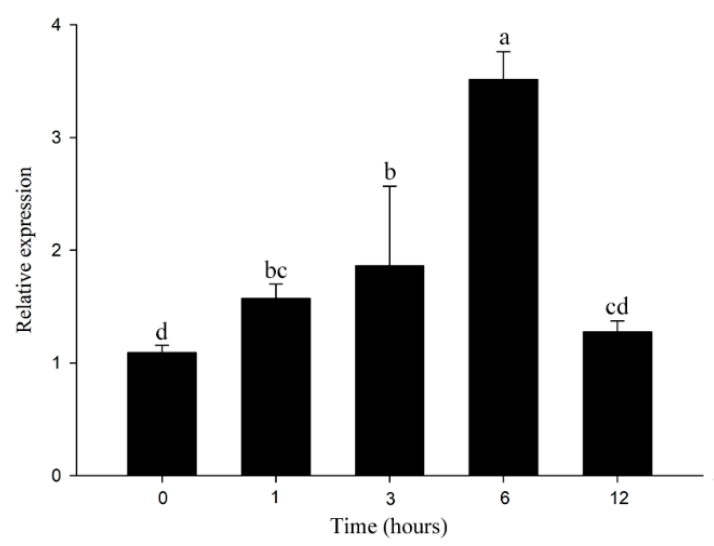

(d)

Figure 5. Expression profiles shows IcSRhO1 gene expresses differently in different tissues including leaf, vine, root, flower and seed (a). The expression of IcSRO1 is induced by different abiotic stressed: (b) Salt, (c) PEG, (d) ABA. The abundance of IcSRO1 transcripts increased to a peak at $6 \mathrm{~h}$ after salt and ABA treatments and decreased at $12 \mathrm{~h}$, while they increased to the peak at $12 \mathrm{~h}$ after PEG treatments. The data represent the means \pm SDs of three independent biological replicates. The different letters in the bar graphs indicate significant differences at $p<0.05$.

\subsection{Overexpression of IcSRO1 Gene in Arabidopsis Enhances Resistance to Salt, Drought and Reduced} ABA Sensitivity

In order to determine the role that IcSRO1 plays in abiotic stresses, transgenic Arabidopsis plants overexpressing IcSRO1 controlled by the CaMV35S promoter were generated. Afterwards, three independent homozygous IcSRO1 T3 lines (35S::IcSRO1-2, 7, 8) were selected for further functional analysis. PCR amplification was used to detect the carrying of IcSRO1 in transgenic plants and Col-0. PCR product at the length of $1800 \mathrm{bp}$ was obtained in three transgenic lines, while none in Col-0. Under normal conditions, seedling growth of transgenic plants shows no evident difference from Col-0. In the other hand, the root lengths of the ICSRO1 overexpressing lines were significantly longer than the Col-0 plants on Murashige \& Skoog (MS) medium contained $150 \mathrm{mM} \mathrm{NaCl}$ (Figure 6), indicating that ICSRO1 transgenic lines had a stronger capacity to resist salt stress.

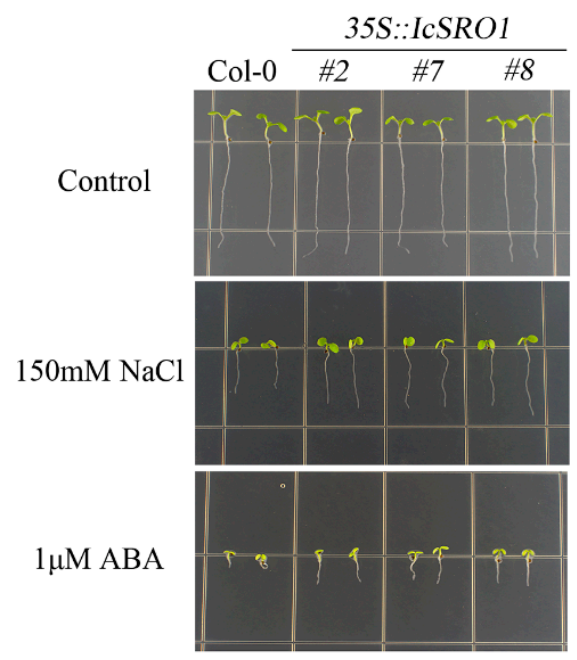

(a)

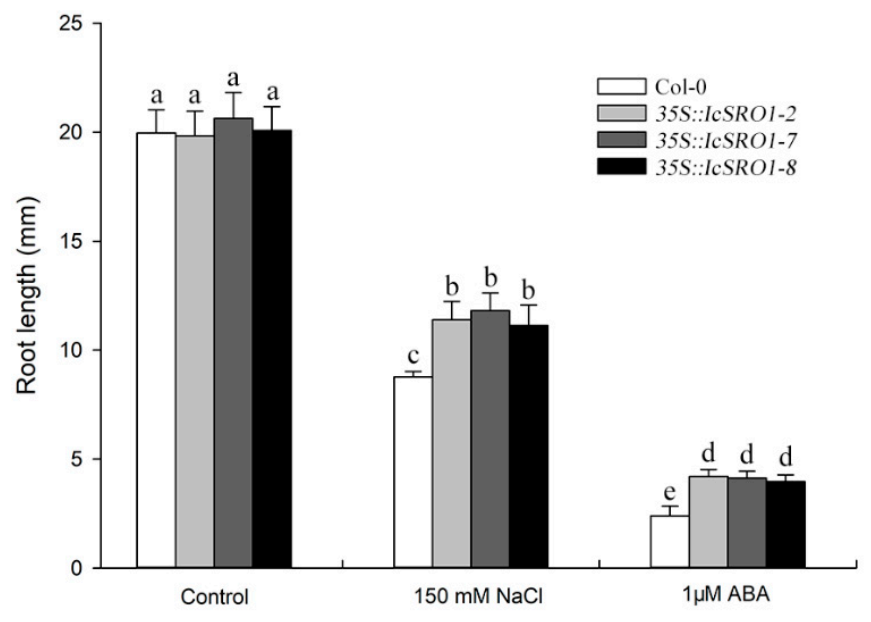

(b)

Figure 6. Cont. 


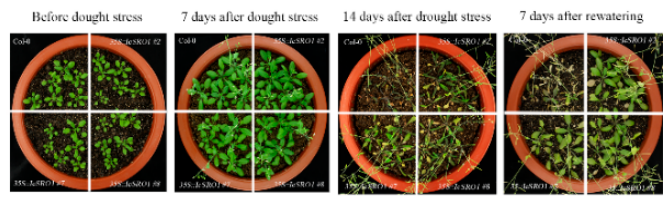

(c)

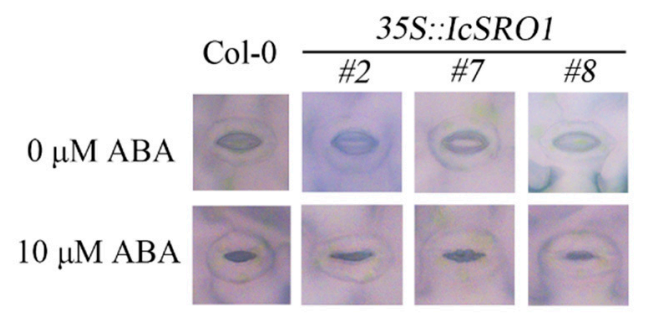

(d)

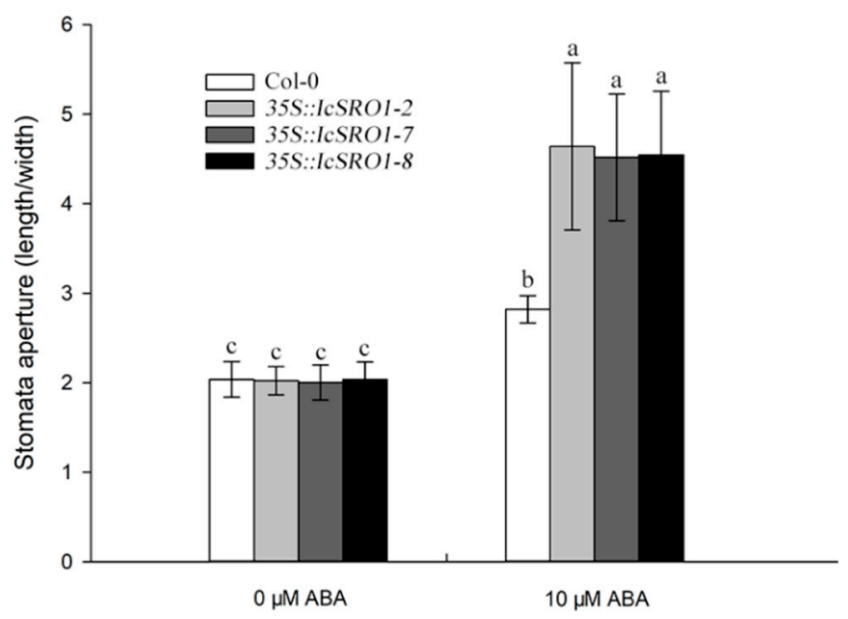

(e)

Figure 6. Overexpressed IcSRO1 in transgenic Arabidopsis improves plant adaptation to salinity and drought stress and reduced the sensitivity to exogenous ABA. (a) The transgenic Arabidopsis and Col-0 seedings were sown on medium containing $0,150 \mathrm{mM} \mathrm{NaCl}$, and $1 \mu \mathrm{M} \mathrm{ABA}$. (b) Length of primary roots was calculated in the transgenic and Col-0 seedings. (c) Drought treatments along with rewetting were applied to 2-week-old transgenic and Col-0 plants. (d,e) Stomatal aperture measurement of Col-0 and IcSRO1 transgenic plants in response to 0 and $10 \mu \mathrm{mol} / \mathrm{L} \mathrm{ABA}$. All the data represent the means \pm SDs. The different letters in the bar graphs indicate significant differences at $p<0.05$.

In order to take a further step to evaluate the significance of IcSRO1 during plant adaptation to drought, 2 weeks of water shortage was applied to transgenic and Col-0 plants which were previously grown under normal condition for 2 weeks. As a result, the drought treatment wilted the most of the Col-0 plants but a few transgenic ones by severe dehydration. The subsequent rewetting restored the IcSRO1 overexpressing lines efficiently, with the survival rates of the transgenic lines (35S::IcSRO1-2, 7, 8) conspicuously higher than that of the Col-0 plants (Figure 6). These results showed that IcSRO1 has a remarkable effect on the resistance of transgenic Arabidopsis against arid condition.

ABA signaling involves in plant responses to multiple abiotic stress. [40]. To achieve a deeper understanding how the ICSRO1 gene functions in response to ABA, corresponding treatments with exogenous $\mathrm{ABA}$ were applied to the transgenic and Col-0 plants during the germination and post-germination growth periods. After exposure to ABA, root length of three transgenic lines showed is significantly longer compared to the Col-0 control (Figure 6), which reveals that exogenous expression of ICSRO1 gene reduced the sensitivity of Arabidopsis to exogenous ABA.

It is agreed that stomatal closure during arid condition could be regulated by ABA [41]. Therefore, as IcSRO1 expression was influenced by ABA, we compared the ABA sensitivity of stomatal closure in IcSRO1 overexpressing transgenic plants with Col-0 controls. When exposed to $10 \mu \mathrm{mol} / \mathrm{L} \mathrm{ABA}$, the stomatal aperture of transgenic lines was smaller than that of Col-0 plants (Figure 6).

\subsection{Determination of $\mathrm{H}_{2} \mathrm{O}_{2}$ and $\mathrm{O}_{2}{ }^{-}$Accumulation}

After salt and drought stress, leaves of transgenic and non-transgenic Arabidopsis were stained by 3,3-diaminobenzidine (DAB) and nitroblue tetrazolium (NBT) to detect the production and distribution of $\mathrm{H}_{2} \mathrm{O}_{2}$ and $\mathrm{O}_{2}{ }^{-}$. Under the optimum condition, no difference shows up between the transgenic and non-transgenic. Stained by DAB, leaves of col- 0 appeared obvious dark-brown color under stress conditions compared to non-stress condition, while leaves of transgenic lines appeared light-brown color under stress conditions. Stained by NBT, leaves of col-0 showed dark-blue under stress conditions compared to non-stress condition, while leaves of transgenic lines showed light-blue under stress 
conditions (Figure 7). The results demonstrate more $\mathrm{H}_{2} \mathrm{O}_{2}$ and $\mathrm{O}_{2}{ }^{-}$accumulation in the non-transgenic plants under salinity and drought stress.

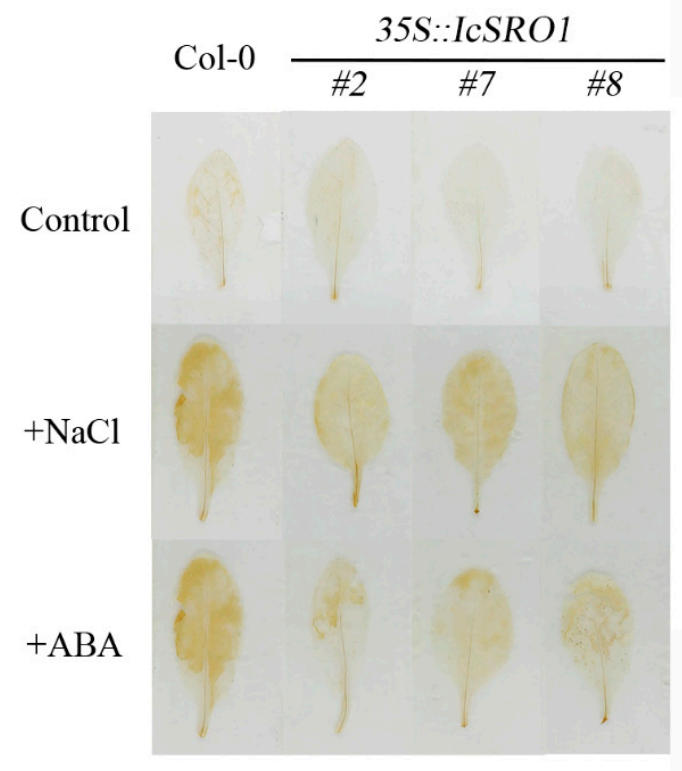

(a)

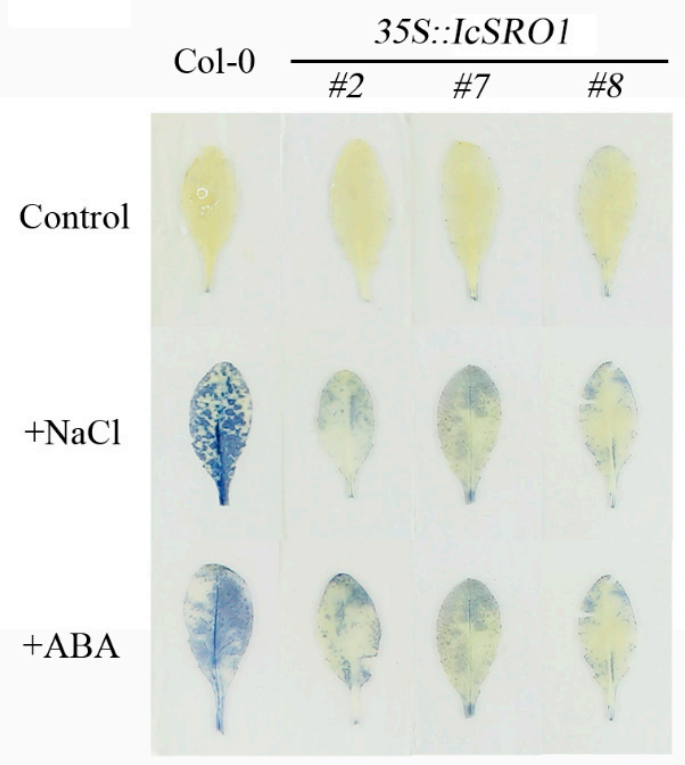

(b)

Figure 7. Accumulation of $\mathrm{H}_{2} \mathrm{O}_{2}$ and $\mathrm{O}_{2}{ }^{-}$under stress conditions demonstrates more $\mathrm{H}_{2} \mathrm{O}_{2}$ and $\mathrm{O}_{2}{ }^{-}$ produced in the Col-0 than in the transgenic lines under salinity and drought stress. Histochemical staining assays were used to detect $\mathrm{H}_{2} \mathrm{O}_{2}$ and $\mathrm{O}_{2}{ }^{-}$by DAB (a) or NBT (b) staining, respectively.

\subsection{IcSRO1 Protein Interacts with AtSOS1 Protein}

Previous studies have shown that AtRCD1 interacted with AtSOS1. In this paper, the interaction between the IcSRO1 protein and AtSOS1 was investigated via Yeast Two-hybrid Assays. The ORF of IcSRO1 was inserted into pGADT7. The trans-membrane domain of AtSOS1 in its N-terminal region was excluded, and the intracellular domain was cloned into the pGBKT7 vector. As shown in Figure 8, all of the yeast transformants grow normally on the double dropout medium while only the (AD-ICSRO1+BD-AtSOS1) yeast transformants survived on the quadruple dropout medium. The results showed that the IcSRO1 protein could interact with the intracellular domain of AtSOS1 protein.

$\mathrm{BD}$

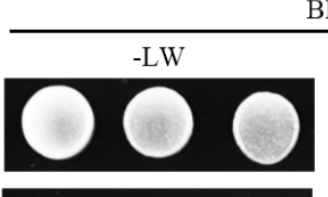

AD-IcSRO1
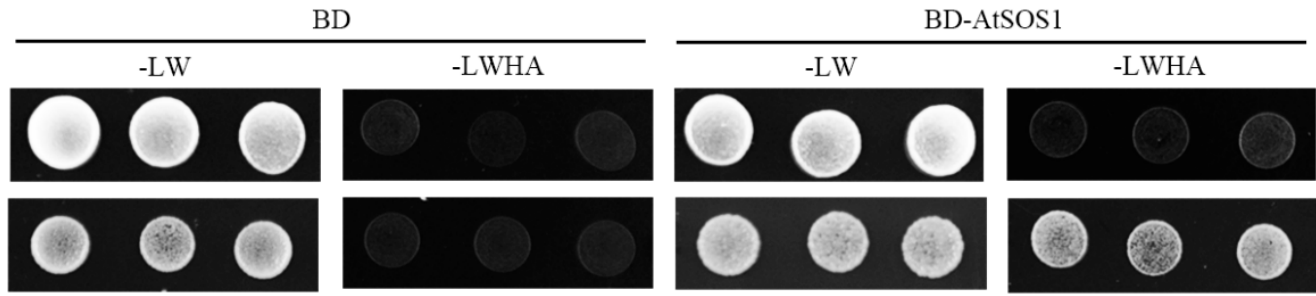

Figure 8. Interaction of IcSRO1 with AtSOS1 determined by yeast cell growth on synthetic dropout (SD) medium lacking Leu, Trp, His, and Ade (SD-LW HA).

\section{Discussion}

Ipomoea cairica, a member of the Ipomoea, distributed in the tropics and have a close relationship with sweet potato. Soil salinity and drought constitute a major factor limiting crop production affecting plant growth and survival. The SRO proteins family remains highly conservative during evolution and is found in many plant species including Arabidopsis, rice, wheat, maize and apple. Previous reports identified several SROs and how they function in different kinds of basic cellular processes. These 
proteins involve in plant adaptation to stress and growth development [20,34,42-44]. Nevertheless, the functions of SROs still remain unknown in perennial creep lianas, especially in members of Ipomoea.

In this paper, we firstly reported the isolation of a new SRO protein from Ipomoea cairica. Sequence alignment along with phylogenetic analysis involving several species demonstrated that the IcSRO1 gene is a putative Ipomoea nil ortholog of the InSRO1 proteins and thus is named IcSRO1. As a typical RADICAL-INDUCED CELL DEATH1 protein, IcSRO1 remains a highly conservative structure similar to its homologies, including a WWE domain, reported as a conserved PARP fold and protein $C$ in the RST function area. In our research the function of IcSRO1 was validated, contributing to a better understanding of the similarities and differences among SRO genes across diverse species. The expression levels of the IcSRO1 gene distinguish in different tissues of I. cairica. It was found that the expression levels are significantly higher in leaves and vine than in root, flower and seed. The expression of IcSRO1 was induced by salt, drought, and ABA, which was similar to that of Arabidopsis by modulating ROS homeostasis $[34,36,38]$. Our results are consistent with previous reports $[45,46]$. In maize, expression of SRO genes was detected in different tissues and plant development stages. Expression of $Z m S R O s$ was similarly regulated by salt, drought, ABA, and gibberellic acid (GA) as well as MdRCD1 In Malus domestica [29]. OsSRO1 was reported as a target gene of SNAC1, which enhances plant sensitivity to abscisic acid. OsSRO1 declines the opening level of stomata and thus lowering transpiration mediated water loss [30,47,48]. In Arabidopsis, DREB2A was reported as a transcription factor inducing expression of downstream genes related to salt and drought resistance and contributed to plant stress-defense [49]. AtDREB2A is located on the ABA-independent signaling pathway [50]. Vainonen et al. found that the AtDREB2A protein stability could be post-translationally regulated by AtRCD1 and the $r c d 1$ mutant is not generally ABA insensitive which indicates the RCD1-DREB2A is probably not acting in ABA signaling [44]. It is implied that IcSRO1 may share the similarity.

During the past several decades, analyses of the functions, structures and other characteristics of genes, were mainly based on model plants like Arabidopsis, Rice and Medicago. To take a deeper look into the function of IcSRO1 under abiotic stress conditions, we overexpressed IcSRO1 in transgenic Arabidopsis Thaliana. Validations of phenotype and physiology indicated that overexpressed IcSRO1 remarkably improves salt and drought tolerance in transgenic plants. Overexpression Triticum aestivum TaSRO1 in Arabidopsis can also improve salt and drought tolerance and simultaneously change the contents of catalase (CAT), ascorbate peroxidase (APX), and glutathione peroxidase (GPX) as well as survival rates [24]. Plants respond to various stresses from external environment by activating enormous and complex signaling systems. Moreover, mutual regulations and cooperation between proteins play a considerable part in stress resistance of plants. Previous studies found that as a cellular hub, AtRCD1 interacts with many transcription factors, such as AtWRKY47, AtbHLH11, and AtSTO, which have been shown to be involved in stress responses [31,47,51]. In addition to transcription factors, AtSOS1, the plasma membrane localization antiporter, interacts through its C-terminal predicted cytosolic tail with AtRCD1. Under non-stress condition, IcSRO1 was localized in nucleus. However, it has also been found that the AtRCD1 is transported out of the nucleus under salt stress conditions suggesting that AtRCD1 plays a critical role in the cross-talk between the ion-homeostasis and oxidative-stress detoxification pathways involved in plant salt tolerance [38]. In our research, IcSRO1 could also interact with intracellular domain of AtSOS1, which suggests that IcSRO1 may have the similar functions. However, the subcellular localization is performed in mesophyll protoplasts, with potential limited gene expression due to heterochromatins and physiological changes caused by cell wall digestion. The gene localization might be influenced by these factors and should be verified further.

In summary, our findings indicated that IcSRO1 shares close homology with AtRCD1 and other SROs. IcSRO1 was localized in nucleus and induced by salt drought and ABA, and interacts with the intracellular domain of AtSOS1. The overexpression of IcSRO1 enhances the adaptation of plants to salt and drought stress. This IcSRO1-involved adaptation may promote the invasion of I. cairica in tropical saline-alkali lands and coastal zones. There is a potential value of I. cairica for improving the 
resistance of sweet potato against environmental stress due to their relationship, which has profound significance for improving breeding programs aimed at improving salt and drought resistance.

\section{Materials and Methods}

\subsection{Plant Material and Growth Conditions}

The I. cairica seeds were collected from the intertidal zone of Qi'ao Island (GPS coordinate: $22.44^{\circ} \mathrm{N}$, $\left.113.63^{\circ} \mathrm{E}\right)$, Zhuhai city, Guangdong province, China. For I. cairica seedling culture, the seeds were sterilized for $5 \mathrm{~min}$ with commercial bleach and washed in sterile water. The seed coats were removed with caution by sandpaper. Coat-removed seeds were placed in Petri plates with two layers of moist filter paper in it, and then transferred to a climate control cabinet (MGC-850HP, Yiheng Technology Co., Ltd., Shanghai, China) for cultivation. The cultivation condition was $25^{\circ} \mathrm{C}, 14 \mathrm{~h} \mathrm{light} / 10 \mathrm{~h}$ dark photoperiod, and $60 \%$ humidity. Seedlings were transferred to half-strength Hoagland's nutrient solution in small black containers under the same growth conditions [52]. The nutrient solution was refreshed every two days.

\subsection{Isolation and Bioinformatics Analysis of IcSRO1}

$100 \mathrm{mg}$ of tissue was taken from each plant and frozen in liquid nitrogen. Total RNA was carefully extracted by TRIzol reagent (Takara, Japan). Absorbance values of the extract at $230 \mathrm{~nm}, 260 \mathrm{~nm}$ and $280 \mathrm{~nm}$ were measured by an Agilent 2100 Bioanalyzer (Agilent Technologies, USA) to check the concentration and purity of the RNA. Gel electrophoresis was used to detect the degradation of RNA. First-strand cDNA was synthesized by PrimeScript ${ }^{\mathrm{TM}}$ RT Reagent Kit with gDNA Eraser (Takara, Japan).

The full-length ORF of ICSRO1 gene was amplified from I. cairica using a PCR method. The cloning primers of the predicted full-length IcSRO1 gene were designed by Primer Premier 6.1 (Primer Biosoft, San Francisco, CA, USA) (Table S1). The gene was amplified using following PCR program: an initial denaturation at $94{ }^{\circ} \mathrm{C}$ for $1 \mathrm{~min}$, followed by 30 cycles at $98{ }^{\circ} \mathrm{C}$ for $10 \mathrm{~s}, 58^{\circ} \mathrm{C}$ for $30 \mathrm{~s}, 72{ }^{\circ} \mathrm{C}$ for $1 \mathrm{~min}$ and a final extension at $72{ }^{\circ} \mathrm{C}$ for $3 \mathrm{~min}$. The amplification products were recycled and then ligated to the pMD-18 vector. The ligation products were subsequently transformed into competent Escherichia coli (E. coli) DH5 $\alpha$. Positive colonies were selected for culture and subjected to PCR detection. The detected positive clones were sequenced (Beijing Genomics Institute, Beijing, China).

The amino acid sequences of IcSRO1 with other RCD1 homologs from different plant species were aligned by the DNAMAN Version 9 (Lynnon Biosoft, San Ramon, CA, USA). Protein physicochemical properties were predicted by online tool Protparam of ExPASy Proteomics Server (http://www.expasy. $\mathrm{ch} /$ tools/protparam.html). The neighbor-joining phylogenetic tree was constructed by MEGA 6.0. Bootstrap values were estimated (with 1000 replicates) to assess the relative support for each branch [53]. The three-dimensional structural models of proteins were predicted using SWISS-MODEL Server (https://swissmodel.expasy.org/). The theoretical $\mathrm{pI}$ and MW of the IcSRO1 protein were predicted via the online computer program pI/MW (http://web.expasy.org/compute_pi/).

\subsection{Subcellular Localization Analysis of IcSRO1}

The open reading frame of the ICSRO1 gene without the termination codon was amplified with specific primers (Table S1) and inserted into the pCambia-1300 expression vector containing the yellow fluorescent protein gene (YFP) under the control of CaMV35S promoter and NOS terminator. The empty vector containing only YFP sequence was used as the control. Leaves of one-week-old seedlings were harvested and the protoplast transformation was conducted according to the method reported by Yoo et al. [54]. After the transformation, the protoplasts were incubated at $23{ }^{\circ} \mathrm{C}$ in an incubator. After $12 \mathrm{~h}$ of incubation, a Zeiss LSM 800 confocal laser (Carl Zeiss, Jena, Germany) scanning microscope was used to observe the subcellular localization of YFP fusion protein. The excitation wavelength 
was $514 \mathrm{~nm}$ and the emission wavelength was 530-600 nm. The chlorophyll auto-fluorescence was recorded simultaneously.

\subsection{Expression Analysis of IcSRO1 Gene in I. cairica}

In order to mimic salinity and drought, and ABA stress treatments, the four-leaf stage seedlings of I. cairica were transferred into half-strength Hoagland's nutrient solutions containing $150 \mathrm{mM} \mathrm{NaCl}$, $20 \%$ PEG 6000 or $10 \mu \mathrm{M}$ ABA. Leaves were collected at $0,1,3,6,12 \mathrm{~h}$ after various treatments to assess the expression patterns of IcSRO1. The time point of $0 \mathrm{~h}$ was set as control. I. cairica ICs were harvested after these treatments. Three biological replicates were taken for each treatment, then quickly placed in liquid nitrogen and stored at $-80{ }^{\circ} \mathrm{C}$ for RNA extraction. The method of RNA extraction was as described previously [55].

Quantitative real-time PCR (qRT-PCR) was completed to assess the expression of IcSRO1 in several stress treatment. qRT-PCR was conducted with the Luna ${ }^{\circledR}$ Universal qPCR Master Mix (New English Biolabs Inc., USA). The operating procedure by Applied Biosystems QuantStudioTM 6 Flex Real-Time PCR system (Applied Biosystems, USA) for qRT-PCR was as follows: Initial denaturation at $95^{\circ} \mathrm{C}$ for $60 \mathrm{~s}$, followed by 40 cycles $\left(15 \mathrm{~s}\right.$ at $95^{\circ} \mathrm{C}, 30 \mathrm{~s}$ at $\left.58^{\circ} \mathrm{C}\right)$, with a melting curve analysis $\left(60-95^{\circ} \mathrm{C}\right.$ at a heating rate of $0.1{ }^{\circ} \mathrm{C}$ per second) to verify the specificity of amplicons. Three technical repetitions were set for each sample. The fluorescence level of each sample observed by qRT-PCR, known as CT values, was normalized by taking the CT value of ICACTIN as a reference. The comparative $2^{-\Delta \Delta C t}$ method was used to calculate the relative expression level of the IcSRO1 in each sample [56].

\subsection{Generation of Transgenic Arabidopsis}

The full-length cDNA of ICSRO1 was amplified by PCR and cloned into the pCambia-1300 under the control of the CaMV35S promoter. The recombinant plasmid was sequenced to confirm that the target gene was inserted correctly. Afterwards, the construct was transferred into Agrobacterium tumefaciens GV3101 as described in the instruction manual of In-Fusion ${ }^{\circledR}$ HD Cloning Kit (TaKara, Kusatsu, Japan). Arabidopsis thaliana was infected with recombinant Agrobacterium tumefaciens by floral-dip method, along with the transformation of target gene. Seeds were harvested after seeding and seeded on sterilized MS medium containing $50 \mathrm{mg}$ kanamycin. After 7 days of cultivation, resistant seedlings were transplanted into Arabidopsis soil and cultured for another 30 days. Validated by PCR, three homozygous transgenic lines with different expression levels were selected for further study.

\subsection{Stress Tolerance Assays with IcSRO1 Overexpressing Transgenic Arabidopsis Plants}

For stress testing of transgenic Arabidopsis overexpressing IcSRO1, Arabidopsis ecotype Columbia (Col-0) was used as the wild-type. In vitro assay for salt tolerance and ABA was conducted as described previously [29]. Transgenic Arabidopsis T3 and Col-0 seeds were sown on MS medium with $150 \mathrm{mM}$ $\mathrm{NaCl}$ and $1 \mu \mathrm{M} \mathrm{ABA}$ for one week at $22{ }^{\circ} \mathrm{C}$ under $16 \mathrm{~h}$ of light, and then their root length was measured.

\subsection{Histochemical Detection of Oxidation Resistance}

The transgenic and Col-0 seedlings, grown on the medium for one week in advance, were transplanted into pots and cultured for another 3 weeks. Drought or salt stress treatments were carried out at the forth week. Plants were droughted by water shortage treatment for two weeks. In salt treatment the plants were subjected to salt stress by watering $150 \mathrm{mM} \mathrm{NaCl}$. Leaves were sampled and stained by NBT and DAB (Sigma-Aldrich, St. Louis, MI, USA) as previously described by Lee et al. with a few modifications [57]. $50 \mathrm{mM}$ PBS with $\mathrm{pH} 6.4$ was used for NBT staining and $50 \mathrm{mM}$ PBS with $\mathrm{pH} 7.0$ was used for DAB staining. 


\subsection{Yeast Two-hybrid Assay}

Vectors pGADT7 and pGBKT7 were used in the yeast two-hybrid assay. The full length of IcSRO1 and intracellular domain of AtSOS1 were constructed on these two vectors respectively. The pGADT7-IcSRO1 and pGBKT7-AtSOS1 vectors were transformed into competent yeast cells and cultured on double dropout medium (SD/-Trp/-Leu) and quadruple dropout medium (SD/-Leu/-Trp/-His/-Ade), respectively. The information of primers used in this study is listed in Table S1.

\subsection{Statistical Analysis}

All the experiments in this study were repeated three times independently and values were shown as the mean $\pm \mathrm{SD}(n=3)$. Data were analyzed by one-way analysis of variance (ANOVA) or two-way ANOVA. The subsequent multiple comparisons were examined based on the least significant difference (LSD) test. $p<0.05$ was considered a significant level. Data analysis was performed with SPSS 21.0 (SPSS Inc., USA). Figures were prepared using Sigmaplot 12.5 (Systat Software Inc., San Jose, CA, USA).

Supplementary Materials: Supplementary materials can be found at http://www.mdpi.com/1422-0067/21/3/1017/ s1.

Author Contributions: S.L. designed the project; B.Y. and M.C. conducted the experiments; Funding acquisition, S.L.; Methodology, B.Y., M.C.; Project administration, S.L.; Writing, B.Y. written draft; S.L. and M.C. revised the manuscript. All authors have read and agreed to the published version of the manuscript.

Funding: This research was funded by the Natural Science Foundation of China (grant number NSFC31670266), the Natural Science Foundation of Guangdong (2017A030313115), and the Guangdong Pearl River Scholar Funded Scheme (2012).

Acknowledgments: We thank Professor Paul Giller from the School of Biological, Earth and Environmental Sciences, University College Cork, Ireland for the $t$ English language editing.

Conflicts of Interest: The authors declare no conflict of interest. The funders had no role in the design of the study; in the collection, analyses, or interpretation of data; in the writing of the manuscript, or in the decision to publish the results.

\section{References}

1. Fang, R.; Staples, G.; Wu, C.; Raven, P. Flora of China. Science Press 1995, 16, 308-309.

2. Huang, Q.Q.; Wu, J.M.; Bai, Y.Y.; Zhou, L.; Wang, G.X. Identifying the most noxious invasive plants in China: Role of geographical origin, life form and means of introduction. Biodivers. Conserv. 2008, 18, 305-316. [CrossRef]

3. Weber, E.; Sun, S.-G.; Li, B. Invasive alien plants in China: Diversity and ecological insights. Biol. Invasions 2008, 10, 1411-1429. [CrossRef]

4. Rajkumar, S.; Jebanesan, A.J.T.B. Repellent activity of selected plant essential oils against the malarial fever mosquito Anopheles stephensi. Trop. Biomed. 2007, 24, 71-75.

5. Geng, Y.; Chen, L.; Lu, H.; Ning, C.; Björn, L.O.; Li, S. Metabolic characteristics of invasive plant Ipomoea cairica in South China by de novo transcriptomics. J. Trop. Subtrop. Bot. 2016, 24, 128-142.

6. Liu, G.; Huang, Q.Q.; Lin, Z.G.; Huang, F.F.; Liao, H.X.; Peng, S.L. High tolerance to salinity and herbivory stresses may explain the expansion of Ipomoea cairica to salt marshes. PLoS ONE 2012, 7, e48829. [CrossRef] [PubMed]

7. Bai, F.; Chisholm, R.; Sang, W.; Dong, M. Spatial risk assessment of alien invasive plants in China. Environ. Sci. Technol. 2013, 47, 7624-7632. [CrossRef]

8. Liu, G.; Gao, Y.; Huang, F.F.; Yuan, M.Y.; Peng, S.L. The invasion of coastal areas in south China by Ipomoea cairica may be accelerated by the ecotype being more locally adapted to salt stress. PLOS ONE 2016, 11, e0149262. [CrossRef]

9. Li, H.; Xing, J.; Ma, D.; Xie, Y.; Li, Q. Identification of virus-resistance characteristics in sweetpotato and its wild relatives. J. Crop. 2003, 3, 11-14.

10. Shabala, S. Learning from halophytes: Physiological basis and strategies to improve abiotic stress tolerance in crops. Ann. Bot. 2013, 112, 1209-1221. [CrossRef] 
11. Qiao, G.; Zhang, X.; Jiang, J.; Liu, M.; Han, X.; Yang, H.; Zhuo, R. Comparative proteomic analysis of responses to salt stress in Chinese willow (Salix matsudana Koidz). Plant Mol. Biol. Rep. 2013, 32, 814-827. [CrossRef]

12. Wang, W.; Vinocur, B.; Altman, A. Plant responses to drought, salinity and extreme temperatures: Towards genetic engineering for stress tolerance. Planta 2003, 218, 1-14. [CrossRef]

13. Deng, W.; Qiu, S.; Liang, Z. Background of Regional Eco-Environment in Da'an Sodic Land Experiment Station of China; Science Press: Beijing, China, 2006; pp. 32-63.

14. Fang, Y.; Xiong, L. General mechanisms of drought response and their application in drought resistance improvement in plants. Cell. Mol. Life Sci. 2015, 72, 673-689. [CrossRef] [PubMed]

15. Munns, R.; James, R.A.; Lauchli, A. Approaches to increasing the salt tolerance of wheat and other cereals. J. Exp. Bot. 2006, 57, 1025-1043. [CrossRef] [PubMed]

16. Yan, K.; Shao, H.; Shao, C.; Chen, P.; Zhao, S.; Brestic, M.; Chen, X. Physiological adaptive mechanisms of plants grown in saline soil and implications for sustainable saline agriculture in coastal zone. Acta Physiol. Plant. 2013, 35, 2867-2878. [CrossRef]

17. Schroeder, J.I.; Delhaize, E.; Frommer, W.B.; Guerinot, M.L.; Harrison, M.J.; Herrera-Estrella, L.; Horie, T.; Kochian, L.V.; Munns, R.; Nishizawa, N.K.; et al. Using membrane transporters to improve crops for sustainable food production. Nature 2013, 497, 60-66. [CrossRef]

18. Agarwal, P.K.; Shukla, P.S.; Gupta, K.; Jha, B. Bioengineering for salinity tolerance in plants: State of the art. Mol. Biotechnol. 2013, 54, 102-123. [CrossRef]

19. Flowers, T.J. Improving crop salt tolerance. J. Exp. Bot. 2004, 55, 307-319. [CrossRef]

20. Jaspers, P.; Blomster, T.; Brosche, M.; Salojarvi, J.; Ahlfors, R.; Vainonen, J.P.; Reddy, R.A.; Immink, R.; Angenent, G.; Turck, F.; et al. Unequally redundant RCD1 and SRO1 mediate stress and developmental responses and interact with transcription factors. Plant J. 2009, 60, 268-279. [CrossRef]

21. Aravind, L. The WWE domain: A common interaction module in protein ubiquitination and ADP ribosylation. Trends Biochem. Sci. 2001, 26, 273-275. [CrossRef]

22. Fujibe, T.; Saji, H.; Arakawa, K.; Yabe, N.; Takeuchi, Y.; Yamamoto, K.T. A methyl viologen-resistant mutant of Arabidopsis, which is allelic to ozone-sensitive rcd1, is tolerant to supplemental ultraviolet-B irradiation. Plant Physiol. 2004, 134, 275-285. [CrossRef] [PubMed]

23. You, J.; Zong, W.; Li, X.; Ning, J.; Hu, H.; Li, X.; Xiao, J.; Xiong, L. The SNAC1-targeted gene OsSRO1c modulates stomatal closure and oxidative stress tolerance by regulating hydrogen peroxide in rice. J. Exp. Bot. 2013, 64, 569-583. [CrossRef]

24. Liu, S.; Liu, S.; Wang, M.; Wei, T.; Meng, C.; Wang, M.; Xia, G. A wheat SIMILAR TO RCD-ONE gene enhances seedling growth and abiotic stress resistance by modulating redox homeostasis and maintaining genomic integrity. Plant Cell 2014, 26, 164-180. [CrossRef] [PubMed]

25. Jiang, H.; Xiao, Y.; Zhu, S. Genome-wide identification, systematic analysis and characterization of SRO family genes in maize (Zea mays L.). Acta Physiol. Plant. 2018, 40, 176. [CrossRef]

26. Babajani, G.; Effendy, J.; Plant, A.L.J.P.S. Sl-SROl1 increases salt tolerance and is a member of the radical-induced cell death 1-similar to RCD1 gene family of tomato. Plant Sci. 2009, 176, $214-222$. [CrossRef]

27. Lv, Y.; Yang, W.; Zhao, L.; Yao, J.; Chen, W.; Li, Y.; Zhang, Y.J.A.A.S. Genome-wide identification and expression analysis of SRO genes family in Gossypium hirsutum L. J. Acta Agron. Sin. 2017, 43, 1468-1479.

28. Anjum, S.; Raza, S.; Azhar, A.; Qamarunnisa, S. Bnsro1: A new homologue of Arabidopsis thaliana rcd1 from Brassica napus. Biologia 2015, 70, 588-598. [CrossRef]

29. Li, H.; Li, R.; Qu, F.; Yao, J.; Hao, Y.; Wang, X.; You, C. Identification of the SRO gene family in apples (Malus $\times$ domestica) with a functional characterization of MdRCD1. Tree Genet. Genom. 2017, 13, 94. [CrossRef]

30. O'Shea, C.; Kryger, M.; Stender, E.G.; Kragelund, B.B.; Willemoes, M.; Skriver, K. Protein intrinsic disorder in Arabidopsis NAC transcription factors: Transcriptional activation by ANAC013 and ANAC046 and their interactions with RCD1. Biochem. J. 2015, 465, 281-294. [CrossRef]

31. O'Shea, C.; Staby, L.; Bendsen, S.K.; Tidemand, F.G.; Redsted, A.; Willemoes, M.; Kragelund, B.B.; Skriver, K. Structures and short linear motif of disordered transcription factor regions provide clues to the interactome of the cellular hub protein Radical-induced Cell Death1. J. Biol. Chem. 2017, 292, 512-527. [CrossRef] 
32. Jaspers, P.; Overmyer, K.; Wrzaczek, M.; Vainonen, J.P.; Blomster, T.; Salojarvi, J.; Reddy, R.A.; Kangasjarvi, J. The RST and PARP-like domain containing SRO protein family: Analysis of protein structure, function and conservation in land plants. BMC Genom. 2010, 11, 170. [CrossRef]

33. Overmyer, K.; Tuominen, H.; Kettunen, R.; Betz, C.; Langebartels, C.; Sandermann, H.; Kangasjärvi, J.J.T.P.C. Ozone-sensitive Arabidopsis rcd1 mutant reveals opposite roles for ethylene and jasmonate signaling pathways in regulating superoxide-dependent cell death. Plant Cell 2000, 12, 1849-1862. [CrossRef]

34. Teotia, S.; Lamb, R.S. RCD1 and SRO1 are necessary to maintain meristematic fate in Arabidopsis thaliana. J. Exp. Bot. 2011, 62, 1271-1284. [CrossRef] [PubMed]

35. Zhu, Y.; Du, B.; Qian, J.; Zou, B.; Hua, J. Disease resistance gene-induced growth inhibition is enhanced by rcd1 independent of defense activation in Arabidopsis. Plant Physiol. 2013, 161, 2005-2013. [CrossRef] [PubMed]

36. Lamb, R.S.; Citarelli, M.; Teotia, S. Functions of the poly(ADP-ribose) polymerase superfamily in plants. Cell. Mol. Life Sci. 2012, 69, 175-189. [CrossRef] [PubMed]

37. Jiang, L.; Wang, Y.; Björn, L.O.; Li, S. Arabidopsis radical-induced cell death1 is involved in UV-B signaling. Photochem. Photobiol. Sci. 2009, 8, 838. [CrossRef]

38. Katiyar-Agarwal, S.; Zhu, J.; Kim, K.; Agarwal, M.; Fu, X.; Huang, A.; Zhu, J.-K. The plasma membrane $\mathrm{Na}^{+} / \mathrm{H}^{+}$antiporter SOS1 interacts with RCD1 and functions in oxidative stress tolerance in Arabidopsis. Proc. Natl. Acad. Sci. USA 2006, 103, 18816-18821. [CrossRef]

39. Wirthmueller, L.; Asai, S.; Rallapalli, G. Arabidopsis downy mildew effector HaRxL106 suppresses plant immunity by binding to RADICAL-INDUCED CELL DEATH1. New Phytol. 2018, 220, 232-248. [CrossRef]

40. Tuteja, N. Abscisic acid and abiotic stress signaling. Plant Signal. Behav. 2014, 2, 135-138. [CrossRef]

41. Schroeder, J.I.; Kwak, J.M.; Allen, G. Guard cell abscisic acid signalling and engineering drought hardiness in plants. Nature 2001, 410, 327. [CrossRef]

42. Fujibe, T.; Saji, H.; Watahiki, M.K.; Yamamoto, K.T. Overexpression of the RADICAL-INDUCED CELL DEATH1 (RCD1) gene of Arabidopsis causes weak rcd1 phenotype with compromised oxidative-stress responses. Biosci. Biotechnol. Biochem. 2006, 70, 1827-1831. [CrossRef] [PubMed]

43. Hiltscher, H.; Rudnik, R.; Shaikhali, J.; Heiber, I.; Mellenthin, M.; Meirelles Duarte, I.; Schuster, G.; Kahmann, U.; Baier, M. The radical induced cell death protein 1 (RCD1) supports transcriptional activation of genes for chloroplast antioxidant enzymes. Front. Plant Sci. 2014, 5, 475. [CrossRef] [PubMed]

44. Vainonen, J.P.; Jaspers, P.; Wrzaczek, M.; Lamminmaki, A.; Reddy, R.A.; Vaahtera, L.; Brosche, M.; Kangasjarvi, J. RCD1-DREB2A interaction in leaf senescence and stress responses in Arabidopsis thaliana. J. Biochem. 2012, 442, 573-581. [CrossRef] [PubMed]

45. Li, X.; Xu, Y.; Liu, F.; Zhao, M.; Sun, Y.; Ma, Q. Maize similar to RCD1 gene induced by salt enhances Arabidopsis thaliana abiotic stress resistance. Biochem. Biophys. Res. Commun. 2018, 503, 2625-2632. [CrossRef] [PubMed]

46. Sharma, S.; Kaur, C.; Singla-Pareek, S.L.; Sopory, S.K. OsSRO1a interacts with RNA binding domain-containing protein (OsRBD1) and functions in abiotic stress tolerance in yeast. Front. Plant Sci. 2016, 7, 62. [CrossRef] [PubMed]

47. Kjaersgaard, T.; Jensen, M.K.; Christiansen, M.W.; Gregersen, P.; Kragelund, B.B.; Skriver, K. Senescence-associated barley NAC (NAM, ATAF1,2, CUC) transcription factor interacts with radical-induced cell death 1 through a disordered regulatory domain. J. Biol. Chem. 2011, 286, 35418-35429. [CrossRef]

48. Negi, S.; Tak, H.; Ganapathi, T.R. A banana NAC transcription factor (MusaSNAC1) impart drought tolerance by modulating stomatal closure and $\mathrm{H}_{2} \mathrm{O}_{2}$ content. Plant Mol. Biol. 2018, 96, 457-471. [CrossRef]

49. Sakuma, Y.; Maruyama, K.; Qin, F.; Osakabe, Y.; Shinozaki, K.; Yamaguchi-Shinozaki, K. Dual function of an Arabidopsis transcription factor DREB2A in water-stress-responsive and heat-stress-responsive gene expression. Proc. Natl. Acad. Sci. USA 2006, 103, 18822-18827. [CrossRef]

50. Agarwal, P.; Jha, B. Transcription factors in plants and ABA dependent and independent abiotic stress signalling. Biol. Plant. 2010, 54, 201-212. [CrossRef]

51. Belles-Boix, E.; Babiychuk, E.; Van Montagu, M.; Inzé, D.; Kushnir, S.J. CEO1, a new protein from Arabidopsis thaliana, protects yeast against oxidative damage. FEBS Lett. 2000, 482, 19-24. [CrossRef]

52. Hoagland, D.R.; Arnon, D.I. The water-culture method for growing plants without soil. Calif. Agric. Exp. Stat. 1950, 347, 32. 
53. Tamura, K.; Stecher, G.; Peterson, D.; Filipski, A.; Kumar, S. MEGA6: Molecular evolutionary genetics analysis version 6.0. Mol. Biol. Evol. 2013, 30, 2725-2729. [CrossRef] [PubMed]

54. Yoo, S.D.; Cho, Y.H.; Sheen, J. Arabidopsis mesophyll protoplasts: A versatile cell system for transient gene expression analysis. Nat. Protoc. 2007, 2, 1565-1572. [CrossRef] [PubMed]

55. Chomczynski, P.; Sacchi, N. The single-step method of RNA isolation by acid guanidinium thiocyanate-phenol-chloroform extraction: Twenty-something years on. J. Nat. Protocol. 2006, 1, 581-585. [CrossRef] [PubMed]

56. Livak, K.J.; Schmittgen, T.D. Analysis of relative gene expression data using real-time quantitative PCR and the 2(-Delta Delta C(T)). Methods 2001, 25, 402-408. [CrossRef] [PubMed]

57. Lee, B.; Lee, H.; Xiong, L.; Zhu, J. A mitochondrial complex I defect impairs cold-regulated nuclear gene expression. Plant Cell 2002, 14, 1235-1251. [CrossRef]

(C) 2020 by the authors. Licensee MDPI, Basel, Switzerland. This article is an open access article distributed under the terms and conditions of the Creative Commons Attribution (CC BY) license (http://creativecommons.org/licenses/by/4.0/). 